\title{
Unraveling the Etiology of North American Grapevine Yellows (NAGY): Novel NAGY Phytoplasma Sequevars Related to 'Candidatus Phytoplasma pruni'
}

Robert E. Davis, Ellen L. Dally, Yan Zhao, Ing-Ming Lee, and Wei Wei, Molecular Plant Pathology Laboratory, United States Department of Agriculture-Agricultural Research Service, Beltsville, MD 20705; Tony K. Wolf and LeAnn Beanland, Alson H. Smith, Jr. Agricultural Research and Extension Center, Virginia Tech, Winchester 22602; Douglas G. LeDoux and David A. Johnson, Missouri Department of Agriculture, Jefferson City 65109; Joseph A. Fiola, University of Maryland Extension, Western MD Research \& Education Center, Keedysville 21756; Hans Walter-Peterson, Cornell Cooperative Extension, Cornell University College of Agriculture and Life Sciences, Penn Yan, NY 14527; Imed Dami, Ohio Agricultural Research and Development Center, The Ohio State University, Wooster 44691; and Mark Chien, Penn State Cooperative Extension, College of Agricultural Sciences, Lancaster, PA 17601

\begin{abstract}
Davis, R. E., Dally, E. L., Zhao, Y., Lee, I.-M., Wei, W., Wolf, T. K., Beanland, L., LeDoux, D. G., Johnson, D. A., Fiola, J. A., Walter-Peterson, H., Dami, I., and Chien, M. 2015. Unraveling the etiology of North American grapevine yellows (NAGY): Novel NAGY phytoplasma sequevars related to 'Candidatus Phytoplasma pruni'. Plant Dis. 99:1087-1097.

North American grapevine yellows (NAGY) disease has sometimes been attributed to infection of Vitis vinifera L. by Prunus X-disease phytoplasma ('Candidatus Phytoplasma pruni') but this attribution may not be fully adequate. In this study, phytoplasma strains related to ' $\mathrm{Ca}$. Phytoplasma pruni' were found in NAGY-diseased grapevines in Maryland, Pennsylvania, Virginia, Ohio, Missouri, and New York State. Based on restriction fragment length polymorphism analysis of $16 \mathrm{~S}$ ribosomal RNA gene (16S rDNA) sequences, the strains (termed NAGYIII strains) were classified in group 16SrIII (X-disease group) but they contained a recognition site for the restriction endonuclease $\mathrm{Mse}$ I that is not present in the $16 \mathrm{~S}$ rDNA of ' $\mathrm{Ca}$. Phytoplasma pruni'. The $16 \mathrm{~S}$ rDNA of the strains differed by three or four nucleotides from that of ' $\mathrm{Ca}$. Phytoplasma pruni', indicating that they belonged to two novel 16S rDNA sequevars, designated NAGYIII $\alpha$ and NAGYIII $\beta$. Both sequevars

differed from ' $\mathrm{Ca}$. Phytoplasma pruni' by a single base in each of three regions corresponding to species-unique (signature) sequences described for ' $\mathrm{Ca}$. Phytoplasma pruni'. Phylogenetic analyses of $16 \mathrm{~S}$ rRNA genes and $\mathrm{SecY}$ proteins, and single-nucleotide polymorphism analyses of $\mathrm{secY}$ and ribosomal protein genes, further distinguished the two grapevine sequevar lineages from one another and from ' $\mathrm{Ca}$. Phytoplasma pruni'. The NAGYIII $\alpha$ and NAGYIII $\beta$ sequevars also differed from ' $C a$. Phytoplasma pruni' in regions of the folded SecY protein that are predicted to be near or exposed at the outer surface of the phytoplasma membrane. No evidence indicated that diseased grapevines contained any phytoplasma strain conforming to 'Ca. Phytoplasma pruni' sensu stricto. Because the NAGYIII sequevars have not been reported in X-disease, a question is raised as to whether NAGYIII and Prunus X-disease are caused by different phytoplasma genotypes.
\end{abstract}

Grape has been cited as the "most valuable agricultural crop in the United States" and "the most valuable horticultural crop in the world" (Ayala 2011; Myles et al. 2011), and grapevine yellows (GY) is one of the most damaging diseases known in Vitis vinifera L. grapevines. The term "grapevine yellows" is applied individually or collectively to any of several diseases of cultivated grapevine. Typical symptoms include shriveling of grape clusters, uneven lignification or maturation of stems (canes), downward rolling of leaves, yellowing or necrosis of leaf veins, reddening of leaves in red grape varieties, dieback of canes, and, in sensitive cultivars, eventual plant death. Although characterized by very similar or indistinguishable symptom syndromes, the GY diseases in different geographic regions of the world are attributed to plant infection by different species of phytoplasmas (formerly mycoplasmalike organisms) that differ from one another in their spread by specific insect vectors, plant host range, and natural ecology (Daire et al. 1997; Davis et al. 1993, 1997a,b, 1998; Engelbrecht et al. 2010; M'hirsi et al. 2004; Olivier et al. 2009; Prince et al. 1993; Quaglino et al. 2013).

Corresponding author: R. E. Davis; E-mail: robert.davis@ars.usda.gov

Accession numbers: KF853433 to KF853459, KF880806 to KF880832, KF915110 to KF915151, and KF990039 to KF990041.

Accepted for publication 29 January 2015.

http://dx.doi.org/10.1094/PDIS-11-14-1185-RE

This article is in the public domain and not copyrightable. It may be freely reprinted with customary crediting of the source. The American Phytopathological Society, 2015.
Phytoplasmas are unique plant-pathogenic bacteria that lack a cell wall, inhabit phloem of diseased plants, are transmitted from plant to plant by phloem-feeding insects (mainly leafhoppers) (Davis and Lee 1982; Weintraub and Beanland 2006; Zhao et al. 2014), and possess chromosomally integrated prophage-based genomic islands termed sequence variable mosaics (Davis et al. 2007; Jomantiene and Davis 2006; Wei et al. 2008a). Taxonomically, phytoplasmas are classified in class Mollicutes (mycoplasmas), along with species of Mycoplasma, Spiroplasma, Acholeplasma, and other genera (Krieg et al. 2011). Attempts to isolate phytoplasmas in culture have been made by researchers since the early 1970 s and, while several claims of axenic culture of phytoplasmas have appeared in the published literature, none has been independently confirmed thus far (Contaldo et al. 2012; Ghosh et al. 1975; Giannotti and Vago 1971; Jacoli 1981; Lin et al. 1970; Lombardo and Pignatelli 1970; Teranaka and Otsuka 1973; Zhao et al. 2014). Thus, phytoplasmas have long remained refractory to many approaches utilized to ascertain phenotypic properties of cultivable bacteria.

Analysis of gene sequences has consequently been adopted for phytoplasma classification and taxonomy (Davis et al. 2013; Lee et al. 1998, 2010; Martini et al. 2007; Quaglino et al. 2013; Zhao et al. 2014). Based on restriction fragment length polymorphism (RFLP) analyses of $16 \mathrm{~S}$ ribosomal RNA genes (16S rDNA), phytoplasmas have been classified in more than 30 groups, and over 35 'Candidatus Phytoplasma' spp. have been described thus far, principally on the basis of comparisons of nucleotide sequence identity of the 16S rRNA gene (Davis et al. 2013; Lee et al. 1998; Nejat et al. 2013; Quaglino et al. 2013). Evolutionary adaptation to survival in widely diverse ecological niches, involving varied insect vectors and plant hosts in different geographic and climatic regions, likely gave rise to divergent radiation of numerous phytoplasma species, 
most of which undoubtedly have not yet been studied. Molecular genetic characterization based on sequence analyses of conserved genes currently remains the most useful approach for distinguishing different phytoplasmas. Because it is difficult, if not impossible, to distinguish the diverse GY diseases from one another based on symptoms alone, genotyping of GY phytoplasma strains forms a critically important basis for understanding etiology and epidemiology of the diseases worldwide, for assessing the impacts of infection by specific GY pathogens, and for devising effective disease management strategies.

In North America, a GY disease was first reported in 1977 in cultivated grapevines in New York State; based on disease symptoms alone, the disease was thought possibly to be flavescence dorée (FD), a GY disease occurring in Europe (Pearson et al. 1985; Uyemoto et al. 1977). These and other findings led to suggestions that the FD phytoplasma, via the insect vector Scaphoideus titanus, was introduced into Europe from North America (Chen et al. 1993; Maixner et al. 1993; Pearson et al. 1985; Uyemoto et al. 1977), although the New York GY phytoplasma had not been definitively identified and characterized. In the 1990s, GY was reported in Virginia (Davis et al. 1998; Prince et al. 1993; Wolf et al. 1994). During 2009 to 2011, a resurgence of GY occurred in Virginia (T. K. Wolf, unpublished), prompting the present study of phytoplasmas associated with the disease, now termed North American grapevine yellows (NAGY), in the eastern United States.

In the current study, we investigated the possible presence and explored the etiology of NAGY disease in the states of Maryland, Pennsylvania, Ohio, and Missouri. We also definitively identified and characterized NAGY phytoplasmas infecting cultivated grapevines in New York State, where NAGY-associated strains had not been clearly identified, and in Virginia, where a more detailed characterization of NAGY phytoplasma strains was needed. An objective of

Table 1. Grapevine cultivars exhibiting symptoms of North American grapevine yellows (NAGY) and found in this study to be infected by 'Candidatus Phytoplasma pruni'-related strains (strains classified in group 16SrIII) in vineyards in Maryland, Virginia, Pennsylvania, New York State, Ohio, and Missouri

\begin{tabular}{|c|c|c|c|c|c|}
\hline \multirow[b]{2}{*}{ State, county } & \multirow[b]{2}{*}{ Vineyard } & \multirow[b]{2}{*}{ Grapevine cultivar } & \multirow[b]{2}{*}{ Year ${ }^{\mathbf{a}}$} & \multicolumn{2}{|c|}{ Phytoplasma } \\
\hline & & & & Strain & Sequevar $^{\mathrm{b}}$ \\
\hline \multicolumn{6}{|l|}{ Maryland } \\
\hline \multirow[t]{9}{*}{ Montgomery } & A & Chardonnay & 2011 & MD1 & $\alpha$ \\
\hline & & Chardonnay & 2011 & MD2 & $\alpha$ \\
\hline & & Chardonnay & 2011 & MD3 & $\alpha$ \\
\hline & & Chardonnay & 2011 & MD4 & $\alpha$ \\
\hline & & Chardonnay & 2011 & MD5 & $\alpha$ \\
\hline & & Chardonnay & 2011 & MD6 & $\beta$ \\
\hline & & Chardonnay & 2011 & MD7 & $\alpha$ \\
\hline & & Chardonnay & 2012 & MD8 & $\alpha$ \\
\hline & & Chardonnay & 2012 & MD9 & $\alpha$ \\
\hline \multirow[t]{4}{*}{ Washington } & B & Pinot gris & 2011 & UMD1 & $\alpha$ \\
\hline & & Chardonnay & 2011 & UMD4 & $\alpha$ \\
\hline & & Chardonnay & 2011 & UMD6 & $\alpha$ \\
\hline & & Black Malvasia & 2011 & UMD7 & $\alpha$ \\
\hline \multirow[t]{2}{*}{ Talbot } & $\mathrm{C}$ & Chardonnay & 2011 & ES1 & $\alpha$ \\
\hline & & Chardonnay & 2011 & ES2 & $\alpha$ \\
\hline \multicolumn{6}{|l|}{ Pennsylvania } \\
\hline Lancaster & D & Chardonnay & 2003 & TW518 & $\beta$ \\
\hline Lancaster & $\mathrm{E}$ & Chardonnay & 2011 & PA1 & $\beta$ \\
\hline \multicolumn{6}{|l|}{ New York State } \\
\hline Schuyler & F & Chardonnay & 2003 & TW285 & $\beta$ \\
\hline Schuyler & G & Chardonnay & 2003 & TW295 & $\beta$ \\
\hline Seneca & $\mathrm{H}$ & Chardonnay & 2003 & TW382 & $\beta$ \\
\hline \multicolumn{6}{|l|}{ Missouri } \\
\hline Warren & I & Unspecified & 2010 & MO9 & $\alpha$ \\
\hline Boone & $\mathrm{J}$ & Unspecified & 2010 & MO12 & $\alpha$ \\
\hline \multicolumn{6}{|l|}{ Virginia } \\
\hline \multirow[t]{2}{*}{ Loudoun } & $\mathrm{K}$ & Chardonnay & 1995 & WC7A & $\alpha$ \\
\hline & & Chardonnay & 1996 & WC11-96 & $\beta$ \\
\hline \multirow[t]{2}{*}{ Rappahannock } & $\mathrm{L}$ & Chardonnay & 1995 & FH13A & $\alpha$ \\
\hline & & Chardonnay & 1996 & FH1-96 & $\alpha$ \\
\hline \multirow[t]{2}{*}{ Fauquier } & M & Cabernet Sauvignon & 2010 & VG1 & $\beta$ \\
\hline & & Cabernet Sauvignon & 2010 & VG14 & $\alpha$ \\
\hline \multirow[t]{4}{*}{ Rappahannock } & $\mathrm{N}$ & Cabernet Sauvignon & 2010 & VG2 & $\alpha$ \\
\hline & & Chardonnay & 2010 & VG3 & $\alpha$ \\
\hline & & Chardonnay & 2010 & VG4 & $\alpha$ \\
\hline & & Chardonnay & 2010 & VG16 & $\alpha$ \\
\hline \multirow[t]{2}{*}{ Rappahannock } & $\mathrm{O}$ & Viognier & 2010 & VG10B & $\alpha$ \\
\hline & & Petit Manseng & 2010 & VG12 & $\alpha$ \\
\hline Rappahannock & $P$ & Malbec & 2010 & VG20 & $\alpha$ \\
\hline \multicolumn{6}{|l|}{ Ohio } \\
\hline \multirow[t]{4}{*}{ Ashtabula } & Q & Chardonnay & 2012 & $\mathrm{OH} 1$ & $\alpha$ \\
\hline & & Chardonnay & 2012 & $\mathrm{OH} 2$ & $\alpha$ \\
\hline & & Chardonnay & 2012 & $\mathrm{OH} 7$ & $\alpha$ \\
\hline & & Chardonnay & 2012 & OH9 & $\alpha$ \\
\hline
\end{tabular}

\footnotetext{
a Year of sample collection.

b Single-nucleotide polymorphism lineage SNP790T/C of 16S rRNA genes; see text for details.
} 
this work was to gain greater understanding of the etiology of NAGY and provide molecular genetic markers that would clearly distinguish NAGY phytoplasma strains and subsequently be useful in identification of insect vectors in epidemiological studies and in disease management. In pursuit of this objective, we used sensitive molecular diagnostic procedures to detect grapevine-infecting phytoplasmas; carried out multilocus genotyping of NAGY phytoplasma strains based on analyses of $16 \mathrm{~S}$ rRNA, secY, and ribosomal protein ( $r p)$ gene sequences; and analyzed the three-dimensional (3D) structure of SecY proteins. A preliminary synoptic report of some of the findings has been published in abstract form (Davis et al. 2012)

\section{Materials and Methods}

Plant samples and DNA amplification. Samples of symptomatic leaves were collected from 39 cultivated grapevine plants (V. vinifera or hybrid) in Maryland, Missouri, New York State, Ohio, Pennsylvania, and Virginia (Table 1). Veins were excised from symptomatic

Table 2. Nucleotide sequences of polymerase chain reaction primers used in this study

\begin{tabular}{llll}
\hline Target & \multicolumn{1}{c}{ Primer } & \multicolumn{1}{c}{ Nucleotide sequence } & Reference \\
\hline rRNA operon & P1 & $5^{\prime}$-AAGAGTTTGATCCTGGCTCAGGATT-3' & Deng and Hiruki, 1991 \\
& P1A & $5^{\prime}$-AACGCTGGCGGCGCGCCTAATAC-3' & Lee et al. 2004b \\
secY region $^{\text {a }}$ & 16S-SR & $5^{\prime}$-GGTCTGTCAAAACTGAAGATG-3' & Lee et al. 2004b \\
& L15F1A(III) & $5^{\prime}$-CTTCTGGTAAAGGACATAAAGG-3' & Lee et al. 2010 \\
& MapR1A(III) & $5^{\prime}$-GGTTCTTCGTGCAATTGCAAACC-3' & Lee et al. 2010 \\
SecYF1(III) & $5^{\prime}$-CTAGACCAGGTTTTGAAGG-3' & Lee et al. 2010 \\
& SecYR1(III) & $5^{\prime}$-GACCTGCTTTTCTCATTATAGC-3' & Lee et al. 2010 \\
& rpL2F3 & $5^{\prime}$-WCCTTGGGGYAAAAAAGCTC-3' & Martini et al. 2007 \\
& rp(I)R1A & $5^{\prime}$-GTTCTTTTGGCATTAACAT-3' & Martini et al. 2007 \\
\hline
\end{tabular}

a This DNA region included the $3^{\prime}$ end of the L15 ribosomal protein gene ( $\left.r p l 15\right)$, the complete $\sec Y$ gene, and the $5^{\prime}$ end of the methionine aminopeptidase gene (map).

b Ribosomal protein ( $r p)$ gene locus encoding S19 ( $r p s S$ gene), L22 ( $r p l V$ gene), and S3 ( $r p s C$ gene).

Table 3. GenBank accession numbers of $16 \mathrm{~S}$ rRNA, $\sec Y$, and ribosomal protein $(r p)$ gene sequences determined in this work

\begin{tabular}{|c|c|c|c|c|c|c|}
\hline \multirow[b]{2}{*}{ State } & \multirow[b]{2}{*}{ Vineyard } & \multirow[b]{2}{*}{ Strain } & \multicolumn{4}{|c|}{ GenBank accession number ${ }^{a}$} \\
\hline & & & $r r n A$ & $r r n B$ & $\sec Y$ & $r p$ \\
\hline \multirow[t]{13}{*}{ Maryland } & $\mathrm{A}$ & MD1 & KF915151 & KF915150 & ND & ND \\
\hline & & MD2 & KF915125 & $\ldots$ & KF853435 & KF880830 \\
\hline & & MD3 & KF915124b & $\ldots$ & ND & ND \\
\hline & & MD4 & KF915149 & KF915148 & KF853436 & KF880829 \\
\hline & & MD6 & KF915147 & KF915146 & KF853437 & KF880828 \\
\hline & & MD8 & KF915145 & KF915144 & KF853438 & KF880827 \\
\hline & & MD9 & KF915123 ${ }^{b}$ & $\ldots$ & KF853439 & KF880826 \\
\hline & B & UMD1 & KF915118 & $\ldots$ & KF853448 & KF880816 \\
\hline & & UMD4 & KF915117 & $\cdots$ & KF853449 & KF880815 \\
\hline & & UMD6 & KF915116 & $\ldots$ & ND & ND \\
\hline & & UMD7 & KF915115 & $\ldots$ & KF853450 & KF880814 \\
\hline & $\mathrm{C}$ & ES1 & KF915129b & $\ldots$ & KF853459 & KF880806 \\
\hline & & ES2 & KF915128b & $\ldots$ & ND & ND \\
\hline \multirow[t]{2}{*}{ Pennsylvania } & $\mathrm{D}$ & TW518 & KF915119b & $\ldots$ & KF853447 & KF880817 \\
\hline & $\mathrm{E}$ & PA1 & KF915137 & KF915136 & KF853458 & KF880823 \\
\hline \multirow[t]{3}{*}{ New York } & $\mathrm{F}$ & TW285 & KF915135 & KF915134 & KF853444 & KF880820 \\
\hline & G & TW295 & KF915133 & KF915132 & KF853445 & KF880819 \\
\hline & $\mathrm{H}$ & TW382 & KF915131 & KF915130 & KF853446 & KF880818 \\
\hline & & & & $\cdots$ & & \\
\hline \multirow[t]{3}{*}{ Missouri } & I & MO9 & KF915122b & $\ldots$ & KF853441 & KF880825 \\
\hline & $\mathrm{J}$ & MO12 & KF915121 ${ }^{\mathrm{b}}$ & $\ldots$ & KF853440 & KF880824 \\
\hline & & $\ldots$ & $\cdots$ & $\ldots$ & $\ldots$ & $\cdots$ \\
\hline \multirow[t]{9}{*}{ Virginia } & $\mathrm{K}$ & WC7A & KF915111 ${ }^{\mathrm{b}}$ & $\ldots$ & KF853457 & KF880808 \\
\hline & & WC11-96 & KF915110 & $\ldots$ & KF853456 & KF880807 \\
\hline & $\mathrm{L}$ & FH13A & KF915126 & $\ldots$ & KF853434 & KF880831 \\
\hline & & FH1-96 & KF915127 & $\ldots$ & KF853433 & KF880832 \\
\hline & M & VG1 & KF915114 ${ }^{\mathrm{b}}$ & $\ldots$ & KF853451 & KF880813 \\
\hline & & VG14 & KF990039 & KF990040 & KF853452 & KF880810 \\
\hline & $\mathrm{N}$ & VG2 & KF915113 & $\ldots$ & KF853454 & KF880812 \\
\hline & & VG3 & KF915112b & $\ldots$ & KF853455 & KF880811 \\
\hline & & VG16 & KF990041 ${ }^{\mathrm{b}}$ & $\ldots$ & KF853453 & KF880809 \\
\hline \multirow{4}{*}{ Ohio } & Q & $\mathrm{OH} 1$ & KF915143 & KF915142 & ND & ND \\
\hline & & $\mathrm{OH} 2$ & KF915141 & KF915140 & KF853442 & KF880822 \\
\hline & & $\mathrm{OH} 7$ & KF915139 & KF915138 & ND & ND \\
\hline & & OH9 & KF915120 b & $\ldots$ & KF853443 & KF880821 \\
\hline
\end{tabular}

a $r r n A$ and $r r n B=$ ribosomal RNA operons $r r n A$ and $r r n B$, respectively. The nucleotide sequence for operon $r r n B$ was determined for strains in which evidence for interoperon sequence heterogeneity was observed in $16 \mathrm{~S}$ rRNA genes. ND $=$ not determined.

b No evidence for interoperon sequence heterogeneity of 16S rRNA genes was observed for this strain. 
leaves and frozen at $-20^{\circ} \mathrm{C}$ until they were used for DNA extraction. DNA for use as template in polymerase chain reactions (PCRs) was extracted from excised veins by a modified method (Green et al. 1999) using DNeasy Plant DNA Extract Kit (Qiagen, Germantown, MD) and stored at $-20^{\circ} \mathrm{C}$ until further use. rRNA gene sequences were amplified in direct high-fidelity (hf)-PCRs primed by primer pair P1/16S-SR, or in seminested PCRs primed by P1/16S-SR followed by P1A/16S-SR, and catalyzed by AccuPrime Taq DNA Polymerase High Fidelity (Life Technologies, Carlsbad, CA) under conditions previously described (Lee et al. 2004a,b). The rp genomic regions containing a partial $\left(3^{\prime}\right.$ end $) r p s \mathrm{~S}$, a complete $r p l V$, and a complete $r p s C$ gene were amplified in nested hf-PCRs primed by primer pair rpL2F3/rp(I)R1A (Martini et al. 2007) followed by rp(III)FN/rp(I)R1A (Davis et al. 2013). SecY genomic regions containing a partial ( $3^{\prime}$ end) $r p l 15 r p$ gene, a complete $\sec Y$ gene, and a partial ( $5^{\prime}$ end) methionine aminopeptidase (map) gene were amplified in hf-PCRs primed by L15F1A(III)/MapR1A(III) and catalyzed by LA Taq DNA polymerase (Takara Bio USA, Madison, WI) followed by nested PCR with primer pair SecYF1(III)/SecYR1(III) under conditions previously described (Lee et al. 2010). Nucleotide sequences of primers are given in Table 2. A negative control devoid of DNA template in the reaction mix was included in all PCR assays. PCR products were analyzed by $1 \%$ agarose gel electrophoresis $(10 \mathrm{~V} / \mathrm{cm})$.

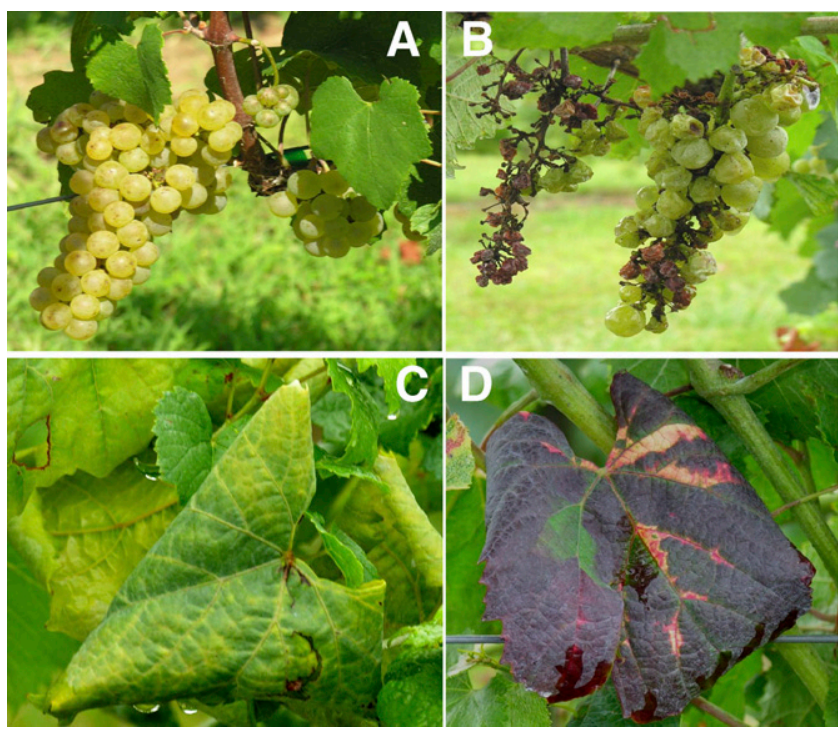

Fig. 1. Symptomatic North American grapevine yellows (NAGY)-diseased and symptomless grapevine (Vitis vinifera) plants. A, Symptomless Chardonnay grapevine. B, NAGY-diseased Chardonnay; note shriveled fruit cluster. C, Symptomatic leaf from NAGY-diseased Chardonnay. D, Symptomatic leaf from NAGY-diseased Black Malvasia.
Phytoplasma-specific DNA bands were extracted from gels using QIAquick Gel Extraction Kit (Qiagen), and amplicons were sequenced by automated DNA sequencing (ABI Prism Model 3730; Applied Biosystems, Foster City, CA) of both strands. GenBank accession numbers of nucleotide sequences determined in this work are given in Table 3. Nucleotide sequences of genes from other phytoplasmas in this study were obtained from the GenBank database (http://www.ncbi.nlm.nih.gov/).

Phytoplasma classification. 16S rRNA gene sequences were subjected to virtual RFLP analyses for group and subgroup classification, and to nucleotide sequence identity comparisons for taxonomic placement, using $i$ PhyClassifier (Zhao et al. 2009) (http://plantpathology. ba.ars.usda.gov/cgi-bin/resource/iphyclassifier.cgi). Input data for $i$ PhyClassifier usage consisted of nucleotide sequences, at least $1.2 \mathrm{~kb}$ in size, including the annealing sites for PCR primers R16F2n and R16R2 (Gundersen and Lee 1996), the minimum 16S rDNA sequence region required by the program. Nucleotide and amino acid sequence alignments were done using the Lasergene software MegAlign program (DNASTAR, Madison, WI).

Protein structure predictions. The amino acid sequences of SecY proteins were deduced from respective $\sec Y$ gene nucleotide sequences using the Lasergene EditSeq program (DNASTAR). The 3D structures of the SecY proteins were predicted using the online modeling program SWISS-MODEL (http://swissmodel.expasy.org/) with the Bacillus subtilis SecY protein as a template (Swiss Model 3d18H). Predicted 3D structures were visualized and analyzed using Swiss PDB-Viewer (Guex and Peitsch 1997).

Phylogenetic analyses. Phylogenetic analyses were accomplished by using the software MEGA4 with the minimum evolution algorithm implemented in the software (Tamura et al. 2007). The initial tree was obtained through close-neighbor-interchange search using the neighbor-joining method. The reliability of the analysis was subjected to a bootstrap test with 1,000 replicates.

\section{Results}

Geographic occurrence of NAGY and classification of associated phytoplasma strains. GY disease symptoms were observed in V. vinifera 'Chardonnay', 'Pinot gris' ('Pinot grigio'), 'Viognier', 'Petit Manseng', 'Cabernet Sauvignon', 'Malbec', and 'Black Malvasia' in the states of Maryland, Missouri, Pennsylvania, Ohio, Virginia, and New York State (Table 1). The findings were new records of the disease for Maryland, Ohio, Pennsylvania, and Missouri. Symptoms observed in white or light-skinned grape cultivars included mild chlorosis of leaf lamina, yellowing and necrosis of leaf veins, necrosis of interveinal tissue, downward curling of leaf margins, incomplete lignification of affected branches, and shriveling of fruit clusters (Fig. 1). In addition, diseased red and dark grape cultivars generally exhibited abnormal reddening of leaf interveinal tissue. Downward rolling of leaf margins was often not observed.
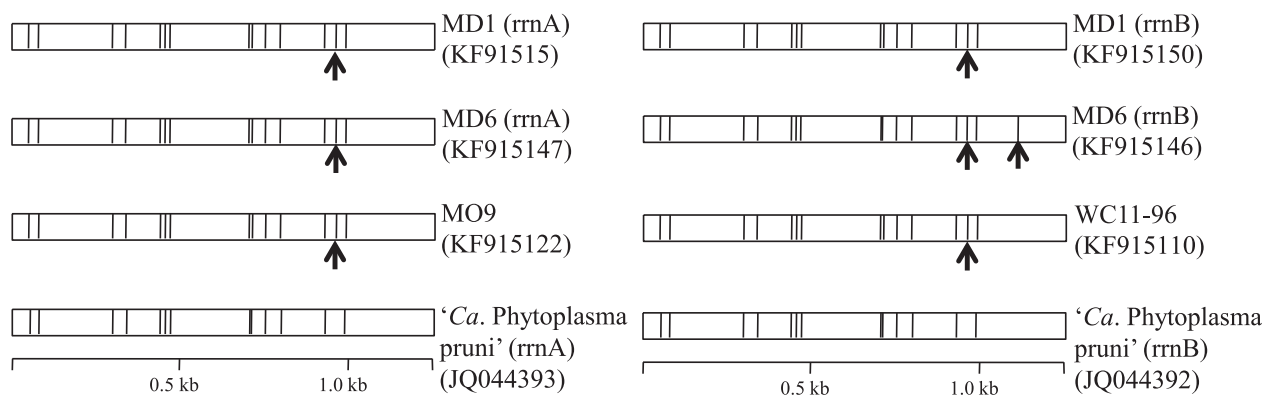

Fig. 2. Analysis of putative restriction sites in $16 \mathrm{~S}$ rRNA gene (rDNA) sequences from North American grapevine yellows phytoplasma strains belonging to group $16 \mathrm{Srlll}$ (North American grapevine yellows [NAGY]III strains) and from 'Candidatus Phytoplasma pruni'. Maps were generated using the MAPDRAW option of the DNASTAR program and manually aligned for comparison of recognition sites for the restriction endonuclease Msel. MD1, MD6, MO9, and WC11-96 = NAGYIII phytoplasma strains. rrnA and rrnB indicate rDNA sequences derived from the two sequence heterogeneous rRNA operons, respectively, in a given phytoplasma genome. No evidence for 16S rRNA interoperon sequence heterogeneity was observed for strains MO9 and WC11-96. Each bar represents the 1,247-bp rDNA segment that is amplified in polymerase chain reaction primed by oligonucleotide pair F2n/R2n and used for group and subgroup classification based on restriction fragment length polymorphism analysis. Vertical lines indicate recognition sites for the restriction endonuclease Msel. GenBank numbers are given in parentheses. Arrows indicate Msel recognition sites that are present in NAGYIII strains and absent in 'Ca. Phytoplasma pruni'. Horizontal scale bars indicate base positions. 
Phytoplasma-characteristic rDNA fragments were amplified in PCRs containing template DNA from all 39 NAGY-symptomatic plants sampled, indicating that all the plants were infected by phytoplasma (Table 1). Based on the results from the virtual RFLP analysis, we classified the NAGY strains in group 16SrIII and termed them NAGYIII phytoplasma strains. The collective RFLP patterns of $16 \mathrm{~S}$ rDNA were highly similar to those of 'Candidatus Phytoplasma pruni', the reference phytoplasma for group 16SrIII, subgroup 16SrIII-A, but

\begin{tabular}{|c|c|c|c|c|c|c|c|}
\hline & \multirow{2}{*}{$\begin{array}{l}\text { Phytoplasm } \\
\text { strain }\end{array}$} & \multicolumn{4}{|c|}{ 16S rRNA gene } & \multirow{2}{*}{$\begin{array}{c}\sec Y \\
308,316,318\end{array}$} & \multirow{2}{*}{$\begin{array}{c}\mathrm{rp}(\mathrm{S} 3 \text { protein gene }) \\
1100,1113 \\
\end{array}$} \\
\hline & & 242 & 790 & 1003 & 1093 & & \\
\hline \multirow{19}{*}{ NAGYIII $\alpha$} & WC7A & GGG & TGTAA & AGGTTATCA & GTTAAT & $\overline{\text { AGATGAAAATTGTAATA }}$ & $\overline{\text { GTATTGATTTATCATGGTGAAG }}$ \\
\hline & FH13A & AGTTGGCAGGG & CGCTGTAA & AGGTTATCA & GTTAАTTGC & TAAGATGAAAATTGTAATA & GTATTGATTTATCATGGTGAAG \\
\hline & FH1-96 & AGTTGGCAGGG & CGCTGTAA & AGGTTATCA & GTTAATTGC & TAAGATGAAAATTGTAATA & GTATTGATTTATCATGGTGAAG \\
\hline & VG2 & AGTTGGCAGGG & CGCTGTAA & AGGTTATCA & GTTAATTGC & TAAGATGAAAATTGTAATA & GTATTGATTTATCATGGTGAAG \\
\hline & VG3 & AGTTGGCAGGG & CGCTGTAA & AGGTTATCA & GTTAATTGC & TAAGATGAAAATTGTAATA & GTATTGATTTATCATGGTGAAG \\
\hline & VG14 & AGTTGGCAGGG & CGCTGTAA & AGGTTATCA & GTTAATTGC & TAAGATGAAAATTGTAATA & GTATTGATTTATCATGGTGAAG \\
\hline & VG16 & AGTTGGCAGGG & CGCTGTAA & AGGTTATCA & GTTAATTGC & TAAGATGAAAATTGTAATA & GTATTGATTTATCATGGTGAAG \\
\hline & MO9 & AGTTGGCAGGG & CGCTGTAA & AGGTTATCA & GTTAATTGC & TAAGATGAAAATTGTAATA & GTATTGATTTATCATGGTGAAG \\
\hline & MO12 & AGTTGGCAGGG & CGCTGTAA & AGGTTATCA & GTTAATTGC & TAAGATGAAAATT & GTATTGATTTATCATGGTGAAG \\
\hline & MD2 & AGTTGGCAGGG & CGCTGTAA & AGGTTATCA & GTTAATTGC & TAAGATGAAAATTGTAATA & GTATTGATTTATCATGGTGAAG \\
\hline & MI & AGTTGGCAGGG & CGCTGTAA & AGGTTATCA & GTTAATTGC & TAAGATGAAAA & GTATTGATT: \\
\hline & MD8 & AGTTGGCAGGG & CGCTGTAA & AGGTTATCA & GTTAATTGC & AAGATGAAA & GTATTGATT: \\
\hline & MD 9 & AGTTGGCAGGG & CGCTGTAA & AGGTTATCA & GTTAATTGC & AAGATGAAAA & GTATTGATTI \\
\hline & & AGTTGGC & CGCTGTAA & AGGTTATAC & GTTAATTGC & AGATGAAA & GTATTGATT \\
\hline & & AGTTGGC & CGCTGTAA & AGGTTATCA & GTTAATTGC & AGATGAAA & GTATTGATTI \\
\hline & 4 & AGTTGGCAGGG & CGCTGTAA & AGGTTATCA & GTTAATTGC & AGATGAAA & GTATTGATTTATCATGGTGAAG \\
\hline & & AGTTGGCAGGG & CGCTGTAA & AGGTTATCA & GTTAATTGC & AAGATGAAA & GTATTGATT: \\
\hline & $\mathrm{OH} 2$ & AGTTGGCAGGG & CGCTGTAA & AGGTTATCA & GTTAATTGC & TAAGATGAAAATTGTAATA & GTATTGATTTATCATGGTGAAG \\
\hline & & AGTTGGCAGGG & CGCTGTAA & AGGTTATCA & GTTAATTGC & & GTATTGATTAACATGGTGAAG \\
\hline \multirow{8}{*}{ NAGYIII $\beta$} & $\overline{\mathrm{WC}} 1 \overline{1}-9 \overline{6}$ & $\overline{A G T T G G C A G G-}$ & $\bar{C} \bar{G}$ ddGTA $\bar{A}$ & AGGTTATCA & GTTA & 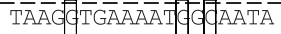 & GTATA \\
\hline & VG1 & AGTTGGCAGGG & CGCdGTAA & AGGTTATCA & GTTAATTGC & TAAGGTGAAAATIGdAATA & GTATGGATTTATCATGGTGAAG \\
\hline & PA1 & AGTTGGCAGGG & CGOdGTAA & AGGTTATCA & GTTAATTGC & TAAGQTGAAAATdGdAATA & GTATAGATTTATCATGGTGAAG \\
\hline & MD 6 & AGTTGGCAGGG & CGddGTAA & AGGTTATCA & GTTAATTGC & TAAGGTGAAAATIGQAATA & GTATAGATTTATCATGGTGAAG \\
\hline & Tw2 85 & AGTTGGCAGGG & CGddGTAA & AGGTTATCA & GTTAATTGC & TAAGQTGAAAATIGGDAATA & GTATGGATTTATCATGGTGAAG \\
\hline & 295 & AGTTGGCAGGG & CGddGTAA & AGGTTATCA & GTTAATTGC & TAAGQTGAAAATIGGAATA & GTATGGATTTATCATGGTGAAG \\
\hline & TW382 & AGTTGGCAGGG & CGOdGTAA & AGGTTATCA & GTTAATTGC & TAAGGTGAAAATIGGDAATA & GTATAGATTTATCATGGTGAAG \\
\hline & & & CGddGTAA & & GTTAATTGC & TAAGGTGAAAATGGDAATA & С \\
\hline \multirow{6}{*}{$\begin{array}{l}\text { 'Ca. } \\
\text { Phytoplasma } \\
\text { pruni' }\end{array}$} & $\operatorname{PX11}-1$ & AGTTGGTAGGG & CGCOCGTAA & AGGTCATCA & GTTAdTTGC & TAAGATGAAAATGGTATA & GTATGGATTTATCATGGDGAAG \\
\hline & PX11-2 & AGTTGGMAGGG & CGddGTAA & AGGTIATCA & GTTAdTTGC & TAAGATGAAAATIGTAATA & GTATGGATTTATCATGGDGAAG \\
\hline & PX92-1 & AGTTGGMAGGG & CGDdGTAA & AGGTCATCA & GTTAddTTGC & TAAGATGAAAATIGGTAATA & GTATGGATTTATCATGGCGAAG \\
\hline & PX92-4 & AGTTGGMAGGG & CGOdGTAA & AGGTCATCA & GTTAdTTGC & TAAGATGAAAATIGTAATA & GTATGGATTTATCATGGdGAAG \\
\hline & $\mathrm{CX}-95$ & AGTTGGTAGGG & CGddGTAA & AGGTIATCA & GTTAdTTGC & TAAGATGAAAATIGGTAATA & GTATAGATTTATCATGGDGAAG \\
\hline & WX95 & AGTTGG凹AGGG & CGddGTAA & AGGTdATCA & GTTA dTTGC & TAAGATGAAAATIGGTAATA & GTATGGATTTATCATGGDGAAG \\
\hline
\end{tabular}

Fig. 3. Selected single-nucleotide polymorphisms (SNPs) in segments of genes encoding 16S rRNA, and SecY and rpS3 proteins, of North American grapevine yellows (NAGY) phytoplasma strains and 'Candidatus Phytoplasma pruni' strains. Representative NAGY strains are shown. Bases distinguishing NAGYIII $\alpha$, NAGYIII $\beta$, and 'Ca. Phytoplasma pruni' from one another are boxed. Numbers indicate base positions of SNPs with reference to 'Ca. Phytoplasma pruni' strain PX11CT1 ${ }^{\mathrm{R}}$ GenBank sequences JQ044393 (16S rRNA bases 242, 790, 1,003, and 1,093), JQ268254 (secY, bases 308, 316, and 318) and JQ360960 (ribosomal protein [rp] locus, bases 1,100 and 1,113). In the present study, strains (NAGYIIl $\alpha$ strains) bearing a T in the 16S rRNA gene SNP790T/C position were found in vineyards in Maryland, Virginia, Ohio, and Missouri; strains (NAGYIII $\beta$ strains) bearing a C in the SNP790T/C position were found in vineyards in Maryland, Virginia, New York, and Pennsylvania. GenBank accession numbers for 16S rRNA gene sequences from 'Ca. Phytoplasma pruni' strains PX11CT1 ${ }^{\mathrm{R}}$ (PX11-1), PX11CT2 (PX11-2), PX92CT1 (PX92-1), PX92CT4 (PX92-4), CX-95, and WX95 are JQ044393, JQ044391, JQ044389, JQ044383, JQ044397, and JQ044396, respectively; those for secY genes are JQ268254, JQ268253, JQ268252, JQ268251, JQ268249, and JQ268250, respectively; and those for rpS3 genes are JQ360960, JQ360959, JQ360958, JQ360957, JQ360955, and JQ360956, respectively.

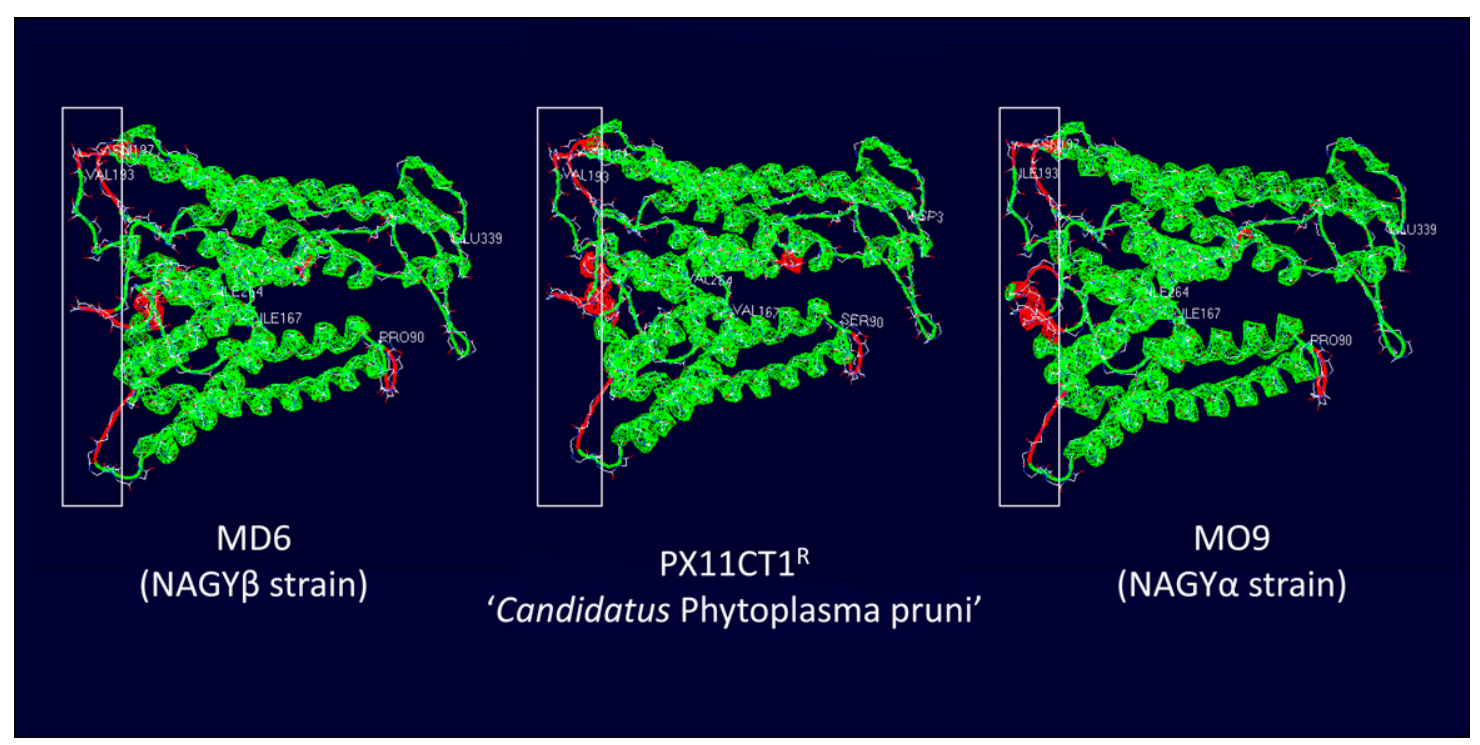

Fig. 4. Predicted three-dimensional structures of the deduced amino acid sequences of the SecY proteins encoded by lineage North American grapevine yellows (NAGY)Ill $\alpha$ strain MO9, lineage NAGYIII $\beta$ strain MD6, and 'Candidatus Phytoplasma pruni' strain PX $11 \mathrm{CT} 1^{\mathrm{R}}$. Differing regions putatively exposed at or present near the outer surface of the phytoplasma membrane are boxed. 


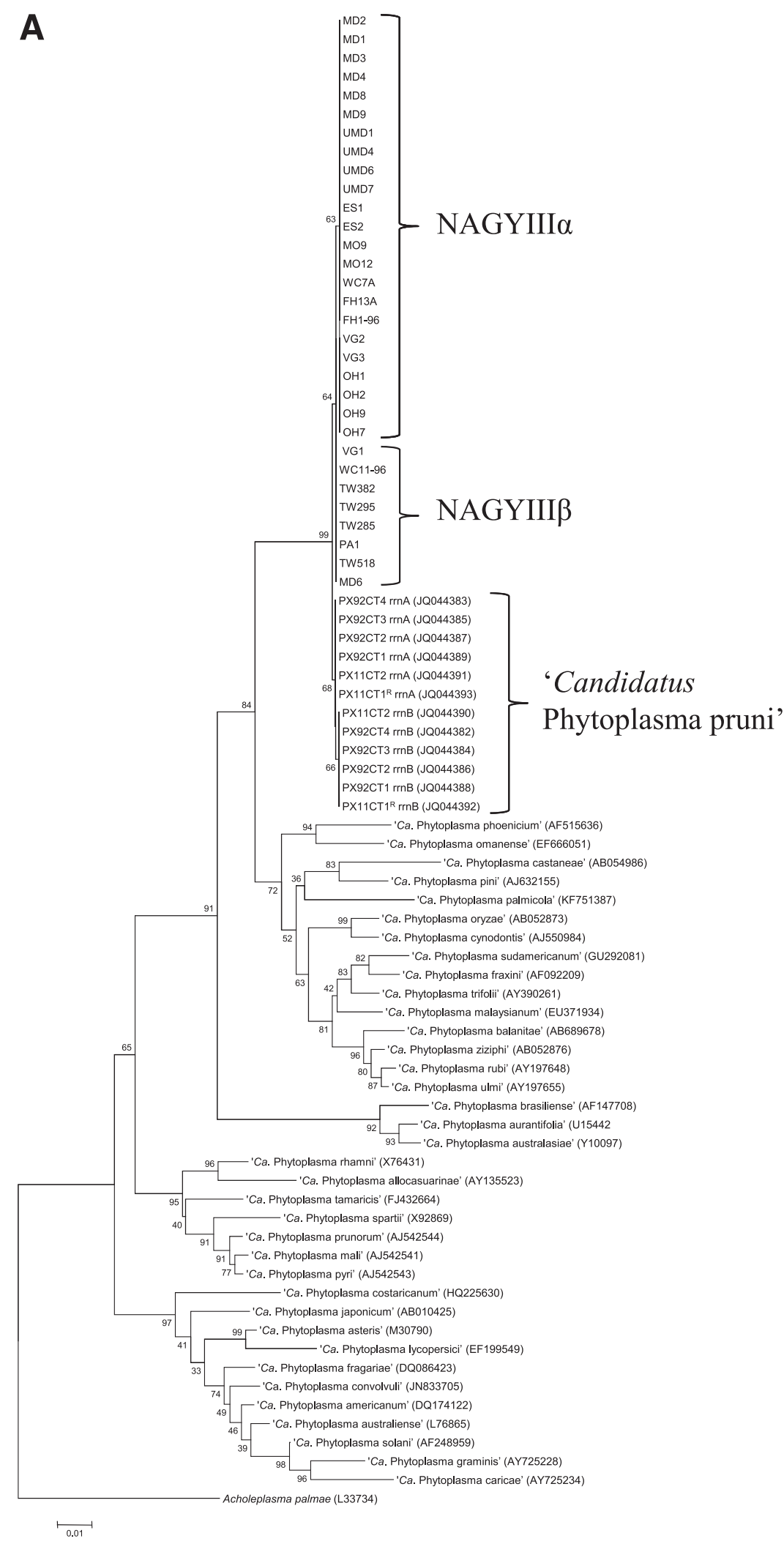

Continued on following page

Fig. 5. Phylogenetic relationships of North American grapevine yellows (NAGY)III phytoplasma strains and reference strains of 'Candidatus Phytoplasma' spp. inferred from analysis of $A$ and $B, 16 S$ rRNA gene sequences and $C$ and $D$, SecY amino acid sequences ( $5 C$ and $5 D)$. $B$ and $D$ are expanded views of portions of $A$ and $C$, respectively. Representative NAGY strains are shown. Acholeplasma palmae was selected to root the trees. NAGYIll $\alpha$ and NAGYIII $\beta$ indicate two distinct sequevar lineages of NAGYII phytoplasma. For analyses of NAGYIII strains exhibiting rRNA interoperon sequence heterogeneity, 16S rRNA gene sequences from rrnA were used. GenBank accession numbers for 16S rDNA sequences from NAGYIII phytoplasma strains are given in Table 3. GenBank numbers for 16S rDNA sequences from other phytoplasma strains are given in parentheses. Amino acid sequences of SecY proteins from NAGYIII strains (C and D) are those encoded by respective nucleotide sequences for which GenBank numbers are listed in Table 3; amino acid sequences of SecY proteins from 'Candidatus Phytoplasma pruni' strains PX92CT4, PX92CT1, PX11CT2, and PX11CT1 ${ }^{R}$ are encoded by GenBank accessions JQ268251 to JQ268254, respectively. GenBank accession numbers for the remaining SecY proteins are given in parentheses. Scale bars indicate the number of base substitutions per site. 
the 16S rDNA of all the grapevine-infecting NAGYIII strains possessed a recognition site for MseI that was not present in strains of ' $\mathrm{Ca}$. Phytoplasma pruni' (Fig. 2). In accordance with revised phytoplasma classification (Wei et al. 2008b), this difference of a single restriction endonuclease recognition site places the NAGYIII strains into a new variant subgroup, designated 16 SrIII-A*. Because all NAGYIII strains in this study were 16 SrIII-A subgroup variants (16SrIII-A*), we reexamined RFLP patterns of $16 \mathrm{~S}$ rDNA from phytoplasma strain VGYIII (strain WC7A, GenBank accession number AF060875), which was previously reported from NAGY-diseased grapevine in Virginia and classified in subgroup 16SrIII-I (Davis et al. 1998). The 16S rDNA RFLP patterns that we obtained included a differentiating $M s e I$ restriction site in the 16S rRNA gene, indicating that strain WC7A should also be classified in variant subgroup 16SrIII-A*.

NAGYIII strains represent two novel sequevars. Alignment of the 16S rDNA nucleotide sequences revealed that each strain was represented by one or the other of two distinct 16S rDNA sequences that shared $>99 \% 16 \mathrm{~S}$ rDNA sequence identity with ' $\mathrm{Ca}$. Phytoplasma pruni' but differed by three or four nucleotides from ' $\mathrm{Ca}$. Phytoplasma pruni' (Fig. 3). To distinguish the strains carrying the two different 16S rDNA sequences, we adopted the term "sequevar", previously used to distinguish walled bacteria. Because "a sequevar consists of the strain or strains which have a particular sequence" (Frothingham and Wilson 1993), we recognized among the NAGYIII strains two novel 16S rDNA sequevars, designated sequevars NAGYIII $\alpha$ and NAGYIII $\beta$ (Table 1; Fig. 3).

A single-nucleotide polymorphism (SNP) in the 16S rRNA genes distinguished the two sequevars. Sequevar NAGYIII $\alpha$ contained a T whereas sequevar NAGYIII $\beta$ contained a $\mathrm{C}$ at the base position equivalent to position 790 in the $16 \mathrm{~S}$ rRNA gene sequence of ' $\mathrm{Ca}$. Phytoplasma pruni' reference strain PX11CT1 ${ }^{\mathrm{R}}$ (GenBank sequence JQ044393). Sequevar NAGYIII $\alpha$ was found in vineyards in Maryland, Virginia, Ohio, and Missouri; sequevar NAGYIII $\beta$ was found in vineyards in Maryland, Virginia, New York, and Pennsylvania (Table 1; Fig. 3). In strains exhibiting 16S rDNA interoperon heterogeneity (Table 3), the operon designated as rrnA matched the $16 \mathrm{~S}$ rDNA sequences of all other strains of a given sequevar.
Unique 16S rRNA gene sequence regions of NAGYIII phytoplasma strains. Because both NAGYIII sequevars are closely related to ' $\mathrm{Ca}$. Phytoplasma pruni', we examined both sequevars for the presence of species-unique 16S rDNA sequences as designated in the original description of ' $\mathrm{Ca}$. Phytoplasma pruni' (Davis et al. 2013). Although both sequevars shared $>99 \%$ 16S rRNA gene sequence identity with ' $\mathrm{Ca}$. Phytoplasma pruni', their $16 \mathrm{~S}$ rRNA genes differed in regions that corresponded to three ' $\mathrm{Ca}$. Phytoplasma pruni'-specific sequences. These nucleotide sequences in the 16S rRNA genes of sequevars NAGYIII $\alpha$ and NAGYIII $\beta$ are 5'-CACATTAGTTAGTTGGCAGGGTAAAGGCCTACC-3', 5'-ATGGAGGTTATCAGGAAA A CAGGTGGTGC-3', and 5' CTTGTCGTTA A TTGCCAGCATGTAAT- $3^{\prime}$. The base positions by which these regions differ from the corresponding ' $\mathrm{Ca}$. Phytoplasma pruni'-specific sequences are underlined, and a recognition site for the restriction endonuclease MseI that distinguishes both sequevars from ' $\mathrm{Ca}$. Phytoplasma pruni' is in italics. Based on these findings, under criteria specified in the original description of ' $\mathrm{Ca}$. Phytoplasma pruni' (Davis et al. 2013) and consistent with earlier guidelines for recognizing ' $\mathrm{Ca}$. Phytoplasma' (IRPCM 2004), sequevars NAGYIII $\alpha$ and NAGYIII $\beta$ should not be termed strains of ' $\mathrm{Ca}$. Phytoplasma pruni' but should be referred to as ' $\mathrm{Ca}$. Phytoplasma pruni'-related strains.

$\operatorname{secY}$ gene SNP lineages among NAGYIII phytoplasmas. We next found evidence that the two novel sequevars NAGYIII $\alpha$ and NAGYIII $\beta$ are also distinguishable from each other and from ' $\mathrm{Ca}$. Phytoplasma pruni' by lineage-specific divergence in the $\sec Y$ gene. In nested PCR, primer pair SecYF1(III)/SecYR1(III) primed amplification of a 1.7-kb DNA fragment that included the partial sequence ( $3^{\prime}$ end) of the L15 rp gene ( $r p l 15$ ), the complete $\sec Y$ gene, and partial sequence $\left(5^{\prime}\right.$ end) of the map gene from sequevars NAGYIII $\alpha$ and NAGYIII $\beta$. Nucleotide sequence alignment revealed that the $\sec Y$ genes in all NAGYIII $\alpha$ strains were identical; the $\sec Y$ genes in all NAGYIII $\beta$ strains were also identical, with the exception of a single base difference in strain TW518. The NAGYIII $\alpha$ and NAGYIII $\beta$ strains shared $99.6 \% \sec Y$ nucleotide sequence identity but both sequevars shared just $98.7 \%$ secY nucleotide sequence

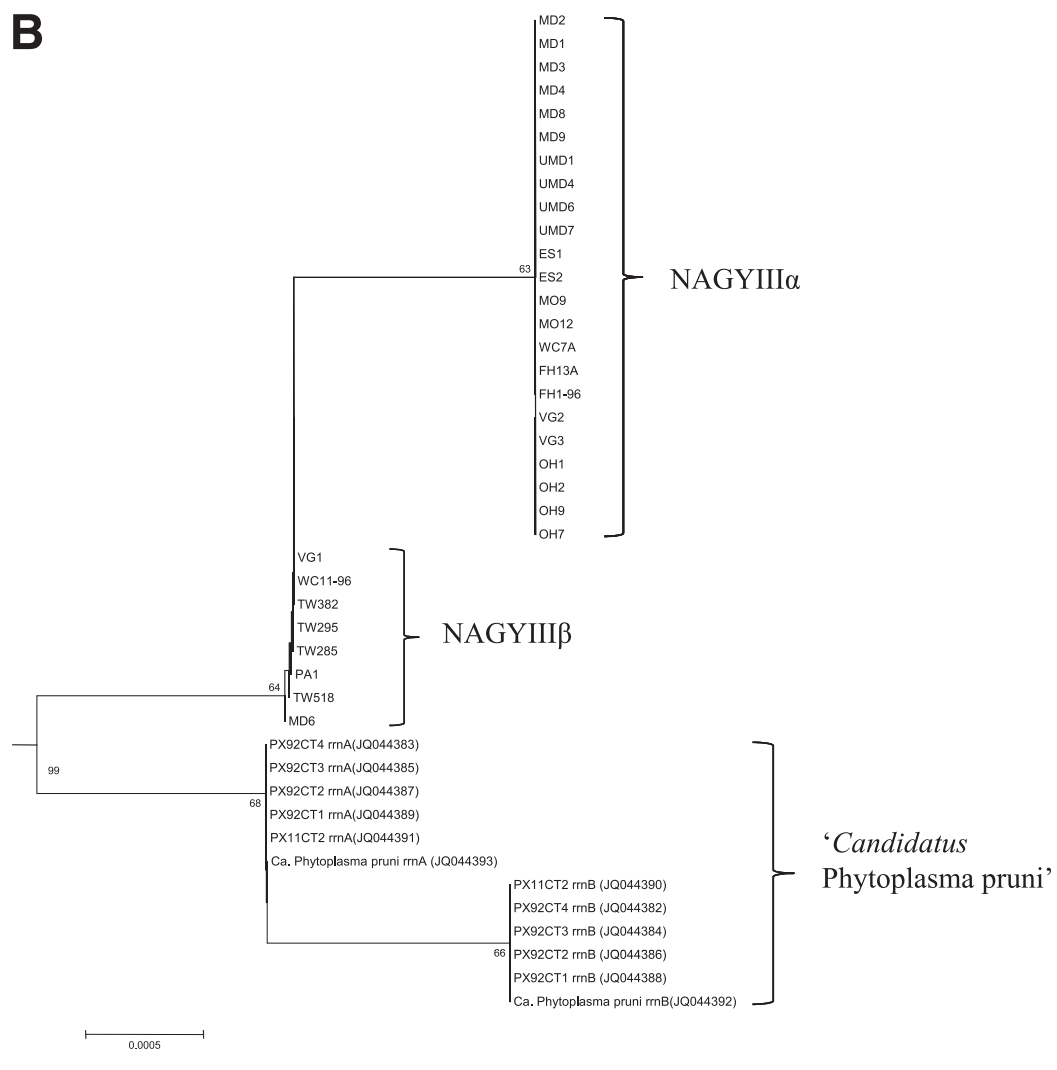

Fig. 5. Continued from previous page. 
identity with ' $\mathrm{Ca}$. Phytoplasma pruni'. The alignment of the $\sec \mathrm{Y}$ nucleotide sequences revealed SNPs at four base positions (Fig. 3; data not shown) that further distinguished sequevars NAGYIII $\alpha$ and NAGYIII $\beta$. One of the SNPs was located in the $\sec Y$ translational start codon.

Results from automated delineation of putative protein coding regions (open reading frames) indicated that the start codon for the $\sec Y$ gene from both NAGYIII $\alpha$ and NAGYIII $\beta$ sequevars was ATG but the deduced amino acid sequences of the encoded sequevar NAGYIII $\beta$ SecY proteins were two amino acids shorter than the SecY proteins encoded by $\sec Y$ genes in sequevar NAGYIII $\alpha$. We further observed that the ATG start codon initially predicted for sequevar NAGYIII $\beta$ was preceded by the triplet GTG, beginning 6 bases upstream of the in-frame ATG; moreover, this GTG was preceded by a purine-rich putative ribosome binding site within 7 to 14 bases upstream of the GTG. For example, this sequence region in strain MD6, as in all other strains of sequevar NAGYIII $\beta$, is as follows: ATATTGAAGGTGGCATAAGGTGAAAATGGCAAT, where the purine-rich region is underlined and bold, as is the newly annotated GTG start codon, while the in-frame ATG is underlined. The corresponding sequence in the $\sec Y$ of strain MO9 and other sequevar NAGYIII $\alpha$ strains is ATATTGAAGGTGGCATAAGATGAAAA TTGTAAT. Based on these observations, we annotate the $\sec Y$ gene of strain MD6 and other sequevar NAGYIII $\beta$ strains with GTG as the translational start codon. Thus, the $\sec Y$ genes of the NAGYIII phytoplasma strains contained either ATG or GTG as the translational start codon; the start codon of $\sec Y$ genes in the sequevar NAGYIII $\alpha$ lineage was ATG, whereas the start codon of $\sec Y$ genes in the sequevar NAGYIII $\beta$ lineage was GTG. All sequevar NAGYIII $\alpha$ secY genes contained an ATG start codon and an in-frame ATT triplet at bases 7 to 9 , whereas, all sequevar NAGYIII $\sec Y$ genes contained GTG as the start codon and an ATG triplet at bases 7 to 9. By contrast, the $\sec Y$ genes of all studied strains of ' $\mathrm{Ca}$. Phytoplasma pruni' had ATG as the translational start codon and contained an in-frame ATG triplet at bases 7 to 9 .

Deduced amino acid sequences and structures of SecY proteins. The SecY-deduced amino acid sequences encoded by sequevars NAGYIII $\alpha$ and NAGYIII $\beta$ differed from that of ' $\mathrm{Ca}$. Phytoplasma pruni' SecY (GenBank number AEY80160) by seven residues (at positions 3, 90, 167, 193, 197, 264, and 339) and six residues (at positions 4, 90, 167, 197, 264, and 339), respectively, and differed from each other by three amino acid residues (positions 3, I [isoleucine] $\rightarrow \mathrm{M}$ [methionine]; 4, V [valine] $\rightarrow$ A [alanine]; and 193, I $\rightarrow$ V). Because differences in mature SecY amino acid sequences may have functional implications for phytoplasmas (Wei et al. 2011), we compared the predicted 3D SecY structures of sequevars NAGYIII $\alpha$ and NAGYIII $\beta$ SecY with that of ' $C a$. Phytoplasma pruni' (strain PX11CT1 ${ }^{\mathrm{R}}$ ). The predicted 3D structures (Fig. 4) indicated that most of the altered amino acid residues in the NAGYIII $\alpha$ and NAGYIII $\beta$ SecY proteins were located at the surface of the folded protein. The surface-exposed regions of the NAGYIII $\alpha$ and NAGYIII $\beta$ SecY proteins differed in 3D structure from the SecY of ' $\mathrm{Ca}$. Phytoplasma pruni'.

SNPs in the $r p$ gene locus of NAGYIII phytoplasmas strains. Sequevars NAGYIII $\alpha$ and NAGYIII $\beta$ were distinguished from ' $C a$. Phytoplasma pruni' by SNPs in the $r p$ gene locus (Fig. 3; data not shown). Some base changes resulted in altered amino acid

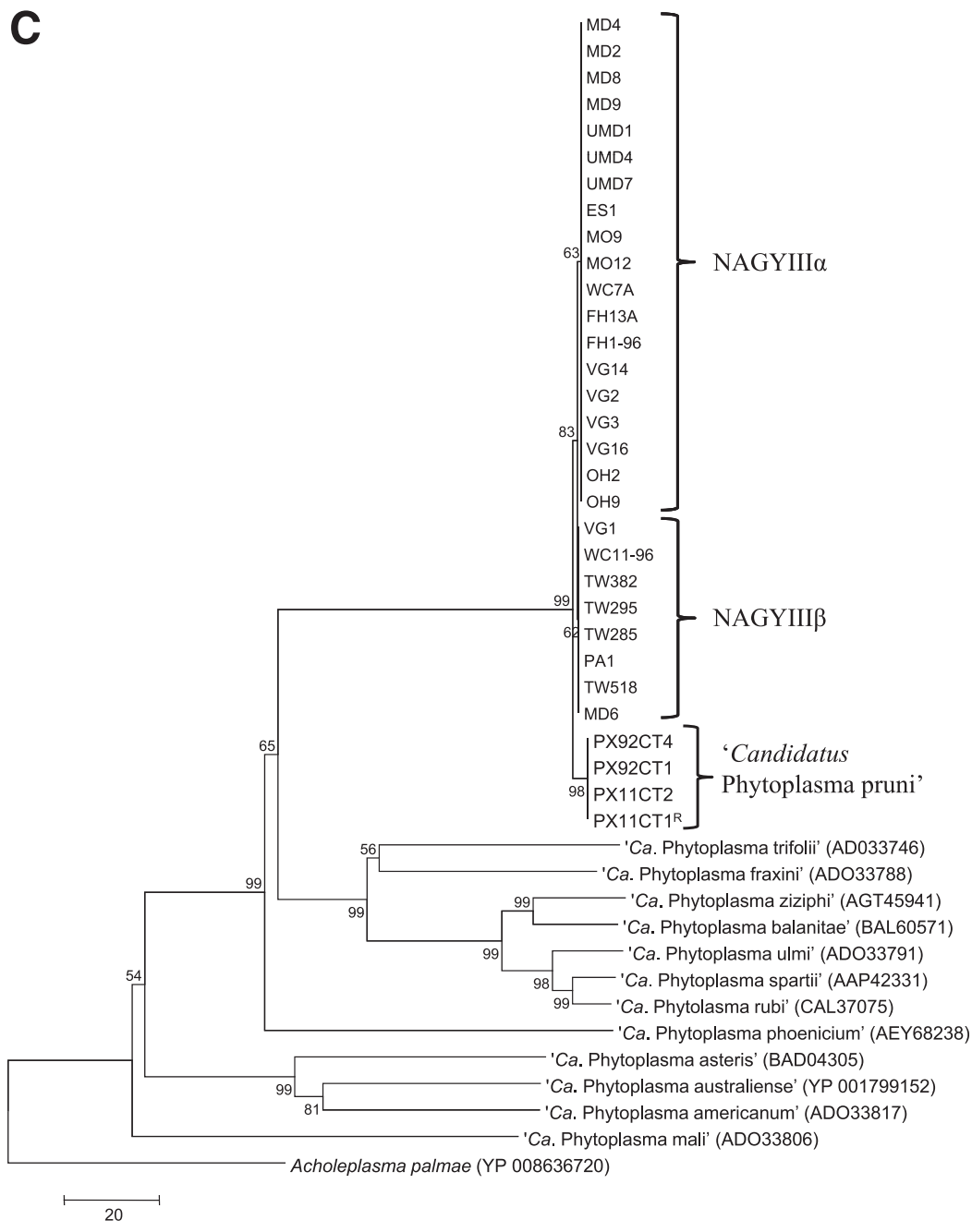

Fig. 5. Continued from previous page. 
composition of encoded S3 proteins. Amino acid substitutions distinguishing the two sequevars from ' $\mathrm{Ca}$. Phytoplasma pruni' included the residues $\mathrm{T}$ (threonine) and Y (tyrosine) in ' $\mathrm{Ca}$. Phytoplasma pruni' versus $\mathrm{K}$ (lysine) and S (serine) in all NAGYIII $\alpha$ and NAGYIII $\beta$ strains examined, at positions 96 and 247, respectively in the S3 protein. An amino acid substitution (W [tryptophan] versus L [leucine] at position 205 in the $\mathrm{S} 3 \mathrm{rp}$ protein) distinguished between the sequevars, consistent with delineation of the two sequevar lineages (this study) on the basis of SNPs in the 16S rRNA and $\sec Y$ gene loci.

Phylogenetic clustering of NAGYIII phytoplasma strains. Relationships inferred from phylogenetic analyses were consistent with the concept that the NAGYIII phytoplasma strains are distinct from strains recognized (Davis et al. 2013) within ' $\mathrm{Ca}$. Phytoplasma pruni' (Fig. 5). Phylogenetic analysis of 16S rRNA genes placed the NAGYIII $\alpha$ and NAGYIII $\beta$ sequevars in close relationship with ' $\mathrm{Ca}$. Phytoplasma pruni', consistent with high gene sequence similarity noted above, and indicated that the NAGYIII strains and ' $\mathrm{Ca}$. Phytoplasma pruni' shared a common ancestor (Fig. 5A). In the expanded view of the region containing the two NAGYIII sequevars and ' $\mathrm{Ca}$. Phytoplasma pruni', none of the NAGYIII strains clustered with ' $\mathrm{Ca}$. Phytoplasma pruni' (Fig. 5B). Phylogenetic analysis based on amino acid sequence of SecY proteins also placed the NAGYIII $\alpha$ and NAGYIII $\beta$ sequevars in close relationship with ' $\mathrm{Ca}$. Phytoplasma pruni' (Fig. 5C), and the two NAGYIII sequevars each formed a branch distinct from that of ' $\mathrm{Ca}$. Phytoplasma pruni' (Fig. 5D).

\section{Discussion}

In this communication, we present evidence of phytoplasmal infection in diverse wine grape cultivars exhibiting symptoms of NAGY across six states. The occurrence of NAGY in diverse red and white wine cultivars points to broad susceptibility of cultivated $V$. vinifera to NAGY phytoplasmal infection, and the distribution of the disease from New York south to Pennsylvania, Maryland, and Virginia and west to Ohio and Missouri suggests that it may occur over a much wider area than presently known.

Because symptoms cannot distinguish NAGY from GY diseases that occur in other regions of the world, correct diagnosis required genotyping of the associated phytoplasma strains. The findings delineated multilocus molecular markers of NAGY group 16SrIII strains in Virginia; provided the first definitive identification of NAGY phytoplasma strains in New York State; and provided the first documented evidence of NAGY in cultivated grapevines in Pennsylvania, Missouri, Ohio, and Maryland. Because NAGY phytoplasma strains studied here have been classified in group 16SrIII (peach X-disease phytoplasma group), the implication might be drawn that NAGY is caused by Xdisease phytoplasma; however, data herein indicate otherwise. Our study provides evidence that the NAGY group 16SrIII phytoplasma strains differ from strains of ' $\mathrm{Ca}$. Phytoplasma pruni' sensu Davis et al. (2013). First, the NAGYIII phytoplasma strains belong to variant subgroup 16SrIII-A*, whereas ' $\mathrm{Ca}$. Phytoplasma pruni' is classified in subgroup 16SrIII-A. Furthermore, the NAGYIII phytoplasma strains represent two novel sequevars, both of which are distinct from ' $\mathrm{Ca}$. Phytoplasma pruni'. 16S rDNA base differences distinguishing the two sequevars (NAGYIII $\alpha$ and NAGYIII $\beta$ ) from ' $\mathrm{Ca}$. Phytoplasma pruni' include one that accounts for the presence of a recognition site for $\mathrm{Mse}$ I that is not present in the $16 \mathrm{~S} \mathrm{rDNA}$ of ' $\mathrm{Ca}$. Phytoplasma pruni'. Significantly, three $16 \mathrm{~S}$ rDNA base differences occurred in regions corresponding to ' $\mathrm{Ca}$. Phytoplasma pruni'-specific sequences designated in the original description of this species (Davis et al. 2013). In accordance with current guidelines for recognizing and naming ' $C a$. Phytoplasma' spp., which state that, "Strains in which even minimal differences in the $16 \mathrm{~S}$ rRNA gene sequences from the reference strain are detected do not 'belong' to the Candidatus species, but are 'related' to it" (IRPCM 2004), the NAGYIII strains should not be termed strains of ' $\mathrm{Ca}$. Phytoplasma pruni'. Instead, the novel NAGYIII sequevars are appropriately termed ' $C a$. Phytoplasma pruni'-related strains. This consequence implies that NAGYIII phytoplasma strains may differ from ' $\mathrm{Ca}$. Phytoplasma pruni' in important yet undescribed biological properties that could illuminate the taxonomic level appropriate for the NAGYIII strains.

As considered previously (Davis and Sinclair 1998), a small difference in 16S rRNA genes can possibly signal differences in other genomic regions and point to lineage divergence that yields distinct gene pools. Here, a single 16S rRNA gene SNP (SNP790T/C) was

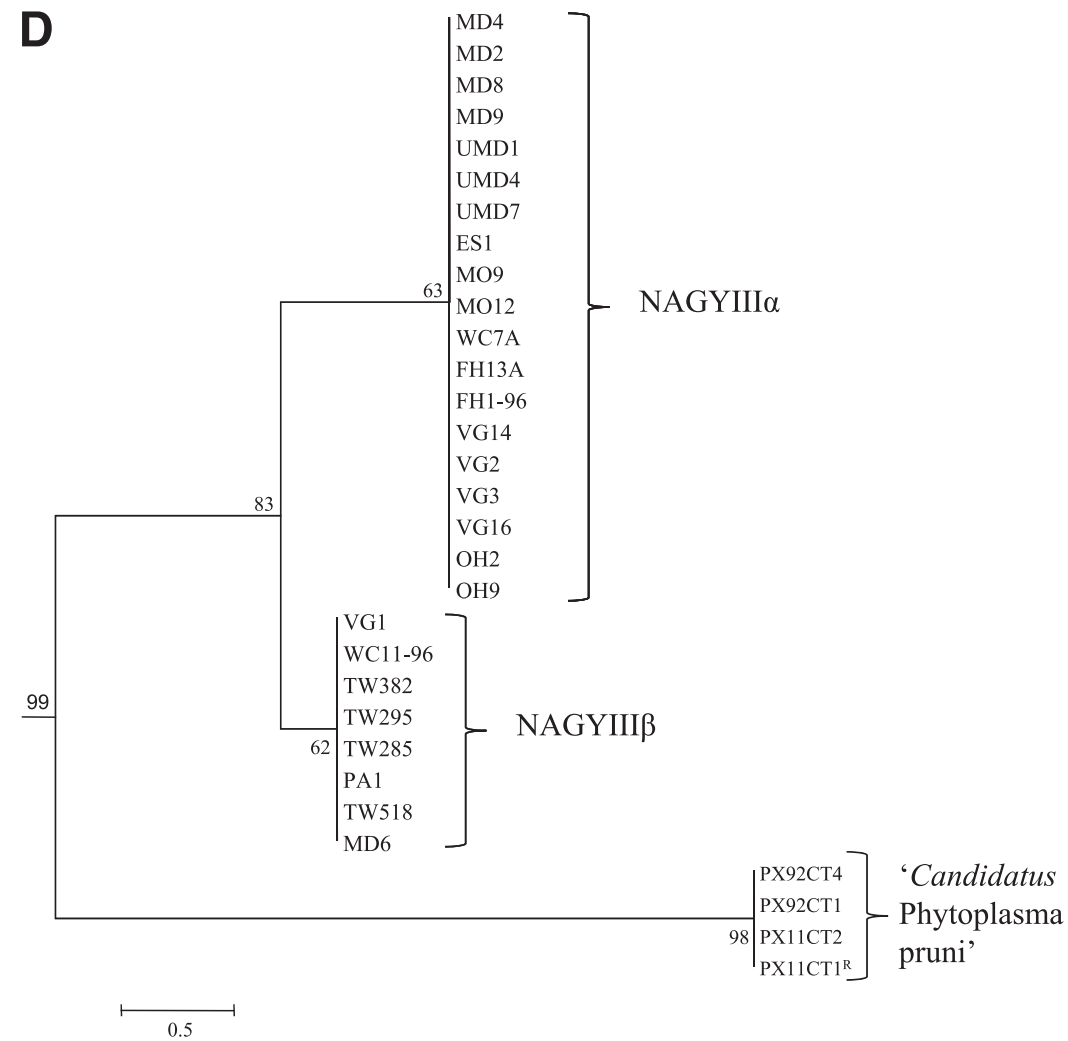

Fig. 5. Continued from previous page. 
predictive of correlative SNPs in $s e c Y$ and $r p$ genes of the NAGYIII phytoplasma strains. For example, sequevar NAGYIII $\alpha$ strains utilize the common ATG start codon for the $\sec Y$ gene, whereas sequevar NAGYIII $\beta$ strains utilize the alternative start codon GTG. Further, 3D modeling of the encoded SecY proteins indicated that the two NAGYIII sequevars also differed from one another and from ' $\mathrm{Ca}$. Phytoplasma pruni' in the identities of SecY amino acids near or exposed at the surface of the phytoplasma membrane in the assembled Sec secretion system. Wei et al. (2011) suggested that differences in amino acid sequence and deduced structure of SecY proteins between phytoplasma strains may have functional implications that are correlated with differences in biology. Thus, differences among NAGYIII sequevars and ' $\mathrm{Ca}$. Phytoplasma pruni' observed in putatively surface-exposed regions of the SecY subunit may differentially impact phytoplasma-host interactions.

Although our observations indicate that different phytoplasma genotypes are associated with NAGYIII and Prunus X-disease, it is feasible that some insect vectors of X-disease phytoplasma may transmit NAGYIII phytoplasma strains. Beanland et al. (2006) reported spatial and temporal distribution of possible leafhopper vectors of NAGY phytoplasmas in Virginia. Some belonged to species previously reported as X-disease vectors and exhibited a seasonal woodland-tovineyard trend in migration throughout the growing season, consistent with the pattern of NAGY disease development within vineyards. The molecular markers documented herein should aid work aimed at elucidating the identities of the NAGY insect vectors. It will be interesting to learn whether the two NAGYIII sequevars differ from one another in specific insect vectorship or plant host range.

\section{Acknowledgments}

We thank the vineyard owners and managers for alerting us to the disease problem in their vineyards and allowing us to collect tissue samples from affected plants, M. Davis for assistance in collecting samples, and J. Shao and J. Smith for assistance in processing samples.

\section{Literature Cited}

Ayala, F. J. 2011. Elixir of life: In vino veritas. Proc. Natl. Acad. Sci. USA 108: 3457-3458.

Beanland, L., Noble, R., and Wolf, T. K. 2006. Spatial and temporal distribution of North American grapevine yellows disease and of potential vectors of the causal phytoplasmas in Virginia. Environ. Entomol. 35:332-344.

Chen, K. H., Guo, J. R., Wu, X. Y., Loi, N., Carraro, L., Guo, Y. H., Chen, Y. D., Osler, R., Pearson, R., and Chen, T. A. 1993. Comparison of monoclonal antibodies, DNA probes, and PCR for detection of the grapevine yellows disease agent. Phytopathology 83:915-922.

Contaldo, N., Bertaccini, A., Paltrinieri, S., Windsor, H. M., and Windsor, D. 2012. Axenic culture of plant pathogenic phytoplasmas. Phytopathol. Mediterr. 51: 607-617.

Daire, X., Clair, D., Reinert, W., and Boudon-Padieu, E. 1997. Detection and differentiation of grapevine yellows phytoplasmas belonging to the elm yellows group and to the stolbur subgroup by PCR amplification on nonribosomal DNA. Eur. J. Plant Pathol. 103:507-514.

Davis, R. E., Dally, E. L., Bertaccini, A., Lee, I.-M., Credi, R., Osler, R., Savino, V., Carrao, L., Di Terlizzi, B., and Barba, M. 1993. Restriction fragment length polymorphism analysis and dot hybridizations distinguish MLOs associated with flavescence dorée and southern European grapevine yellows in Italy. Phytopathology 83:772-776

Davis, R. E., Dally, E. L., Gundersen, D. E., Lee, I.-M., and Habili, N. 1997a. 'Candidatus Phytoplasma australiense', a new phytoplasma taxon associated with Australian grapevine yellows. Int. J. Syst. Bacteriol. 47:262-269.

Davis, R. E., Dally, E. L., Tanne, E., and Rumbos, I. C. 1997b. Phytoplasmas associated with grapevine yellows in Israel and Greece belong to the stolbur phytoplasma subgroup 16SrXII-A. J. Plant Pathol. 79:181-187.

Davis, R. E., Dally, E. L., Zhao, Y., Lee, I., Wolf, T. K., Beanland, L., Fiola, J. A., Chien, M., and Walter-Peterson, H. C. 2012. Grapevine yellows from New York to Virginia: Multilocus molecular genetic characterization of phytoplasmas affecting commercial vineyards. (Abstr.) Phytopathology 102:S3.2.

Davis, R. E., Jomantiene, R., Dally, E. L., and Wolf, T. K. 1998. Phytoplasmas associated with grapevine yellows in Virginia belong to group 16SrI, subgroup A (tomato big bud phytoplasma subgroup), and group 16SrIII, new subgroup I. Vitis 37:131-137.

Davis, R. E., Jomantiene, R., and Zhao, Y. 2007. Dynamic structures in phytoplasma genomes: Sequence-variable mosaics (SVMs) of clustered genes. Bull. Insectol. 60:119-120.

Davis, R. E., and Lee, I.-M. 1982. Pathogenicity of spiroplasmas, mycoplasmalike organisms, and vascular-limited fastidious walled bacteria. Pages 491-513 in:
Phytopathogenic Prokaryotes, Vol. 1. M. Mount and G. Lacy, eds. Academic Press, New York.

Davis, R. E., and Sinclair, W. A. 1998. Phytoplasma identity and disease etiology. Phytopathology 88:1372-1376.

Davis, R. E., Zhao, Y., Dally, E. L., Lee, I.-M., Jomantiene, R., and Douglas, S. M 2013. 'Candidatus Phytoplasma pruni', a novel taxon associated with $\mathrm{X}$-disease of stone fruits, Prunus spp.: Multilocus characterization based on 16S rRNA, secY, and ribosomal protein genes. Int. J. Syst. Evol. Microbiol. 63:766-776.

Deng, S., and Hiruki, C. 1991. Genetic relatedness between two nonculturable mycoplasmalike organisms revealed by nucleic acid hybridization and polymerase chain reaction. Phytopathology 81:1475-1479.

Engelbrecht, M., Joubert, J., and Burger, J. T. 2010. First report of aster yellows phytoplasma in grapevines in South Africa. Plant Dis. 94:373.

Frothingham, R., and Wilson, K. H. 1993. Sequence-based differentiation of strains in the Mycobacterium avium complex. J. Bacteriol. 175:2818-2825.

Ghosh, S. K., Raychaudhuri, S. P., Chenulu, V. V., and Varma, A. 1975. Isolation, cultivation and characterization of mycoplasma-like organisms from plants. Proc. Indian Natl. Sci. Acad. 41:362-366.

Giannotti, J., and Vago, C. 1971. Role des mycoplasmes dans l'étiologie de la phylloidie du Trèfle: Culture et transmission expérimentale de la maladie. Physiol. Veg. 9:541-553.

Green, M. J., Thompson, D. A., and MacKenzie, D. J. 1999. Easy and efficient DNA extraction from woody plants for the detection of phytoplasmas by polymerase chain reaction. Plant Dis. 83:482-485.

Guex, N., and Peitsch, M. C. 1997. SWISS-MODEL and the Swiss-PdbViewer: An environment for comparative protein modeling. Electrophoresis 18: 2714-2723.

Gundersen, D. E., and Lee, I.-M. 1996. Ultrasensitive detection of phytoplasmas by nested-PCR assays using two universal primer pairs. Phytopathol. Mediterr. 35:144-151.

IRPCM (International Research Program for Comparative Mycoplasmology) 2004. 'Candidatus Phytoplasma', a taxon for the wall-less, non-helical prokaryotes that colonize plant phloem and insects. Int. J. Syst. Evol. Microbiol. 54:1243-1255.

Jacoli, G. G. 1981. Attempts to culture in vitro mycoplasma-like organisms from plants, a retrospective view. Phytopathol. Z. 102:148-152.

Jomantiene, R., and Davis, R. E. 2006. Clusters of diverse genes existing as multiple, sequence-variable mosaics in the phytoplasma genome. FEMS Microbiol. Lett. 255:59-65.

Krieg, N. R., Staley, J. T., Brown, D. R., Hedlund, B. P., Paster, B. J., Ward, N. L. Ludwig, W., and Whitman, W. B. 2011. Bergey's Manual of Systematic Bacteriology, Vol. 4, 2nd ed. Springer, New York.

Lee, I.-M., Bottner-Parker, K. D., Zhao, Y., Davis, R. E., and Harrison, N. A. 2010 Phylogenetic analysis and delineation of phytoplasmas based on secY gene sequences. Int. J. Syst. Evol. Microbiol. 60:2887-2897.

Lee, I.-M., Gundersen-Rindal, D. E., Davis, R. E., and Bartoszyk, I. M. 1998 Revised classification scheme of phytoplasmas based on RFLP analyses of $16 \mathrm{~S}$ rRNA and ribosomal protein gene sequences. Int. J. Syst. Bacteriol. 48: $1153-1167$

Lee, I.-M., Gundersen-Rindal, D. E., Davis, R. E., Bottner, K. D., Marcone, C., and Seemüller, E. 2004a. 'Candidatus Phytoplasma asteris', a novel phytoplasma taxon associated with aster yellows and related diseases. Int. J. Syst. Evol. Microbiol. 54:1037-1048

Lee, I.-M., Martini, M., Marcone, C., and Zhu, S. F. 2004b. Classification of phytoplasma strains in the elm yellows group (16SrV) and proposal of 'Candidatus Phytoplasma ulmi' for the phytoplasma associated with elm yellows. Int. J. Syst. Evol. Microbiol. 54:337-347.

Lin, S. C., Lee, C. S., and Chin, R. J. 1970. Isolation and cultivation of, and inoculation with a mycoplasma causing white leaf disease of sugarcane. Phytopathology 60:795-797.

Lombardo, G., and Pignatelli, P. 1970. Cultivation in a cell-free medium of a mycoplasma-like organism from Vinca rosea with phyllody symptoms of the flowers. Ann. Microbiol. Enzymol. 20:84-89.

Maixner, M., Pearson, R. C., Boudon-Padieu, E., and Caudwell, A. 1993 Scaphoideus titanus, a possible vector of grapevine yellows in New York. Plant Dis. 77:408-413.

Martini, M., Lee, I.-M., Bottner, K. D., Zhao, Y., Botti, S., Bertaccini, A., Harrison, N. A., Carraro, L., Marcone, C., Khan, A. J., and Osler, R. 2007. Ribosomal protein gene-based phylogeny for finer differentiation and classification of phytoplasmas. Int. J. Syst. Evol. Microbiol. 57:2037-2051.

M'hirsi, S., Acheche, H., Fattouch, S., Boccardo, G., Marrackchi, M., and Marzouki, N. 2004. First report of phytoplasmas in the aster yellows group infecting grapevine in Tunisia. Plant Pathol. 53:521.

Myles, S., Boyko, A. R., Owens, C. L., Brown, P. J., Grassi, F., Aradhya, M. K., Orins, B., Reynolds, A., Chia, J.-M., Ware, D., Bustamante, C. D., and Buckler E. S. 2011. Genetic structure and domestication history of the grape. Proc. Natl. Acad. Sci. USA 108:3530-3535

Nejat, N., Vadamamli, G., Davis, R. E., Harrison, N. A., Sijam, K., Dickinson, M., Abdullah, S. N. A., and Zhao, Y. 2013. 'Candidatus Phytoplasma malaysianum', a novel taxon associated with virescence and phyllody of Madagascar periwinkle (Catharanthus roseus). Int. J. Syst. Evol. Microbiol. 63:540-548.

Olivier, C. Y., Lowery, D. T., Stobbs, L. W., Vincent, C., Galka, B., Saquez, J., Bittner, L., Johnson, R., Rott, M., Masters, C., and Green, M. 2009. First 
report of aster yellow phytoplasmas ('Candidatus Phytoplasma asteris') in Canadian grapevines. Plant Dis. 93:669.

Pearson, R. C., Pool, R. M., Gonsalves, D., and Goffinet, M. C. 1985. Occurrence of flavescence dorée-like symptoms on 'White Riesling' grapevines in New York, U.S.A. Phytopathol. Mediterr. 24:82-87.

Prince, J. P., Davis, R. E., Wolf, T. K., Lee, I.-M., Mogen, B. D., Dally, E. L., Bertaccini, A., Credi, R., and Barba, M. 1993. Molecular detection of diverse mycoplasmalike organisms (MLOs) associated with grapevine yellows and their classification with aster yellows, X-disease, and elm yellows MLOs. Phytopathology 83:1130-1137.

Quaglino, F., Zhao, Y., Casati, P., Bulgari, D., Bianco, P. A., Wei, W., and Davis, R. E. 2013. 'Candidatus Phytoplasma solani', a novel taxon associated with stolbur and bois noir-related diseases of plants. Int. J. Syst. Evol. Microbiol. 63:2879-2894.

Tamura, K., Dudley, J., Nei, M., and Kumar, S. 2007. MEGA4: Molecular Evolutionary Genetics Analysis (MEGA) software version 4.0. Mol. Biol. Evol. 24:1596-1599.

Teranaka, M., and Otsuka, K. 1973. Culture of mycoplasma-like organisms associated with several witches' broom and aster yellow plants on artificial media. Coll. Agric. Utsunomiya Univ. Bull. 8:11-19.

Uyemoto, J. K., Cummins, J. R., and Abawi, G. S. 1977. Virus and virus-like diseases affecting grapevine in New York vineyards. Am. J. Enol. Vitic. 28:131-136.

Wei, W., Cai, H., Jiang, Y., Lee, I.-M., Davis, R. E., Ding, Y., Yuan, E., Chen, H., and Zhao, Y. 2011. A new phytoplasma associated with little leaf disease in azalea: Multilocus sequence characterization reveals a distinct lineage within the aster yellows phytoplasma group. Ann. Appl. Biol. 158:318-330.

Wei, W., Davis, R. E., Jomantiene, R., and Zhao, Y. 2008a. Ancient, recurrent phage attacks and recombination shaped dynamic sequence-variable mosaics at the root of phytoplasma genome evolution. Proc. Natl. Acad. Sci. USA 105:11827-11832.

Wei, W., Lee, I.-M., Davis, R. E., Suo, X., and Zhao, Y. 2008b. Automated RFLP pattern comparison and similarity coefficient calculation for rapid delineation of new and distinct phytoplasma $16 \mathrm{Sr}$ subgroup lineages. Int. J. Syst. Evol. Microbiol. 58:2368-2377.

Weintraub, P. G., and Beanland, L. 2006. Insect vectors of phytoplasmas and their control. Annu. Rev. Entomol. 51:91-111.

Wolf, T. K., Prince, J. P., and Davis, R. E. 1994. Occurrence of grapevine yellows in Virginia vineyards. Plant Dis. 78:208.

Zhao, Y., Davis, R. E., Wei, W., Shao, J., and Jomantiene, R. 2014. Phytoplasma genomes: Evolution through mutually complementary mechanisms, gene loss and horizontal acquisition. Pages 235-271 in: Genomics of Plant-Associated Bacteria. D. C. Gross, A. Lichens-Park, and C. Kole, eds. Springer, Berlin, Heidelberg.

Zhao, Y., Wei, W., Lee, I.-M., Shao, J., Suo, X., and Davis, R. E. 2009. Construction of an interactive online phytoplasma classification tool, iPhyClassifier, and its application in analysis of the peach X-disease phytoplasma group (16SrIII). Int. J. Syst. Evol. Microbiol. 59:2582-2593. 